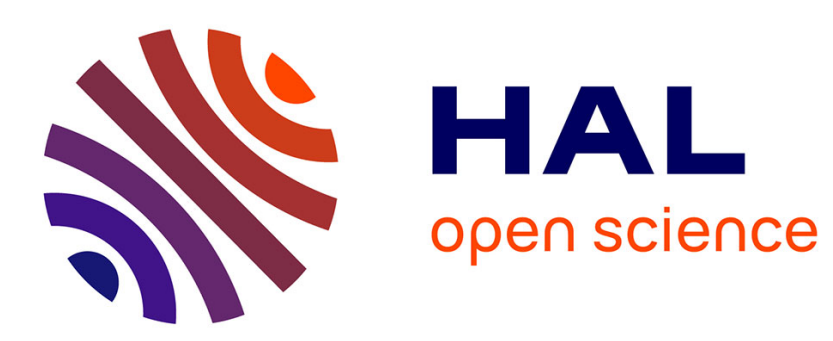

\title{
First spatial distribution of potentially toxic benthic dinoflagellates in the Lesser Antilles (Guadeloupe and Martinique), Caribbean Sea
}

\author{
Aurélie Boisnoir, Pierre-Yves Pascal, Sophie Marro, Rodolphe Lemée
}

\section{- To cite this version:}

Aurélie Boisnoir, Pierre-Yves Pascal, Sophie Marro, Rodolphe Lemée. First spatial distribution of potentially toxic benthic dinoflagellates in the Lesser Antilles (Guadeloupe and Martinique), Caribbean Sea. Botanica Marina, 2019, 62 (4), pp.309-322. 10.1515/bot-2018-0002 . hal-02355800

\author{
HAL Id: hal-02355800 \\ https://hal.science/hal-02355800
}

Submitted on 8 Nov 2019

HAL is a multi-disciplinary open access archive for the deposit and dissemination of scientific research documents, whether they are published or not. The documents may come from teaching and research institutions in France or abroad, or from public or private research centers.
L'archive ouverte pluridisciplinaire HAL, est destinée au dépôt et à la diffusion de documents scientifiques de niveau recherche, publiés ou non, émanant des établissements d'enseignement et de recherche français ou étrangers, des laboratoires publics ou privés. 


\title{
First spatial distribution of potentially toxic benthic dinoflagellates in the Lesser Antilles (Guadeloupe and Martinique), Caribbean Sea
}

\begin{abstract}
For the first time, distribution and abundances (cells per gram of fresh macrophyte weight) of potentially toxic benthic dinoflagellates were studied around Guadeloupe (20 sites) and Martinique (six sites) islands (Lesser Antilles, Caribbean Sea). Benthic dinoflagellates were identified at the genus level and cell counts were undertaken on different host species of macroalgae and seagrasses. Abundance values of potentially toxic benthic dinoflagellates were one order of magnitude higher in Guadeloupe than in Martinique. The highest abundances of benthic dinoflagellates were found in the northern part of Guadeloupe Island, while their distribution was more homogeneous in Martinique. Ostreopsis was the dominant genus in Guadeloupe and Martinique. Regarding biotic substrate preferences, Phaeophyceae hosted the highest total abundances of benthic dinoflagellates on both islands, while the lowest total abundances were observed on Ulvophyceae in Guadeloupe and Florideophyceae in Martinique. The genus Gambierdiscus, known as the causal agent of the ciguatera fish poisoning (CFP), developed on all macrophyte groups on both islands without showing any preferences towards biotic substrates. The presence of this potentially harmful dinoflagellate genus in both islands could explain the existence of local cases of CFP in Guadeloupe and Martinique islands.
\end{abstract}

*Corresponding author: Rodolphe Lémée, Sorbonne Université, CNRS, Laboratoire d'Océanographie de Villefranche, LOV, F-06230 Villefranche-sur-Mer, France, e-mail: lemee@obs-vlfr.fr

Aurélie Boisnoir: Sorbonne Université, CNRS, Laboratoire d'Océanographie de Villefranche, LOV, F-06230 Villefranche-sur-Mer, France; and Institut de Systématique, Évolution, Biodiversité, ISYEB, UMR 7205, CNRS, MNHN, SU, EPHE, Université des Antilles, Équipe Biologie de la mangrove. UFR SEN, 97100 Pointe-à-Pitre, France

Pierre-Yves Pascal: Institut de Systématique, Évolution, Biodiversité, ISYEB, UMR 7205, CNRS, MNHN, SU, EPHE, Université des Antilles, Équipe Biologie de la mangrove. UFR SEN, 97100 Pointe-à-Pitre, France

Sophie Marro: Sorbonne Université, CNRS, Laboratoire d'Océanographie de Villefranche, LOV, F-06230 Villefranche-sur-Mer, France

Keywords: Caribbean Sea; ciguatera; dinoflagellates; Gambierdiscus; Ostreopsis.

\section{Introduction}

Several species of benthic dinoflagellates can generate harmful algal blooms (HABs), sometimes leading to poisoning through the production of toxins (Yasumoto et al. 1987, Holmes and Teo 2002). These phycotoxins synthesized by benthic dinoflagellates can cause ecological damage with significant mass mortalities of marine organisms (Shears and Ross 2009) as well as severe seafood poisoning through the consumption of contaminated fish products by humans (Valdiglesias et al. 2013). Several Ostreopsis species are able to synthesize palytoxins which are probably the cause of palytoxicosis and clupeotoxism revealed after consuming contaminated fish and crustaceans in tropical areas (Alcala et al. 1988, Randall 2005). Most species belonging to the genus Gambierdiscus Adachi et Fukuyo are described as the causal agent of ciguatera fish poisoning (CFP). Species of this genus synthesize ciguatoxins (Bagnis 1981, Yasumoto et al. 1987) that accumulate within different levels of the food chain (Ledreux et al. 2014) and make the consumption of some carnivorous fish more dangerous for the human population compared to other marine organisms at lower levels of the food chain (Pérez-Arellano et al. 2005). CFP is the most widespread non-bacterial food poisoning associated with the consumption of tropical fish (Tester et al. 2009) and impacts several islands of the Pacific Ocean (incidence rate (IR): 18,000 cases $/ 100,000$ inhabitants), Indian Ocean (IR $<10,000$ cases/100,000 inhabitants) and Caribbean Basin (IR: 12-500 cases/100,000 inhabitants) (Chinain et al. 2014). Some benthic species of the genus Prorocentrum 
Ehrenberg can cause illness in humans through diarrhetic shellfish poisoning (DSP) due to the presence of okadaic acid in seafood (Tripuraneni et al. 1997, Lee et al. 2016). Several species of Coolia Meunier and Amphidinium Claparède et Lachmann are able to synthesize toxins which affect marine life, but the bioaccumulation of these toxins through the marine food chain has not yet been proven (Holmes et al. 1995, Botana 2014, Ben-Gharbia et al. 2016). To our knowledge, the implications of Coolia, Amphidinium and Sinophysis species for human health have not been reported nor proven. Moreover, these genera are often found associated with the other genera listed above, making the relation to toxicity difficult to establish.

CFP is considered the most significant health hazard due to tropical fish consumption apart from bacterial contamination. The survey of CFP and associated poisoning can be performed using three main methods: (i) epidemiological studies, (ii) assessment of toxins in organisms at different trophic levels, and (iii) abundance measurement and distribution of microalgae responsible for poisoning. In the Caribbean, currently available data suggest that there is a wide variability regarding the attention given to CFP (Tester et al. 2009). Monitoring and/or ecological studies involving the distribution of benthic dinoflagellates have already been undertaken in the Gulf of Mexico (Okolodkov et al. 2007, 2014), the Florida Keys (Norris et al. 1985) and in Caribbean islands such as the Bahamas Archipelago (Bomber et al. 1988), Cuba (Delgado et al. 2005), Virgin Islands (Carlson and Tindall 1985) and Puerto Rico (Ballantine et al. 1985, 1988). Toxin identification studies associated with CFP in marine organisms have also been performed in the northern part of the Lesser Antilles, in St Martin and St Barthélemy (Bagnis 1981, Bourdeau and Bagnis 1989). Since 2002, a decree prohibits the fishing and commercialization of several fish species in both islands. Epidemiological studies dating from 1996 to 2006 revealed that the highest incidence rates of CFP were reported in Antigua-Barbuda and Montserrat with 34 and 59 cases per 10,000 inhabitants per year, respectively (Tester et al. 2010).

The territories north of Martinique presented a higher prevalence of ciguatera compared to the south (Olsen et al. 1984), so that Guadeloupe and Martinique are respectively inside and outside of the high prevalence area. For both islands, all CFP cases were reported to the Regional Health Agency thereby triggering epidemiological surveys, which showed that the frequency of CFP outbreaks was stable in Guadeloupe between 2013 and 2016 (Boucaud-Maitre et al. 2018), while CFP cases decreased in Martinique between 1998 and 2007 (Rosine et al. 2008). Despite the presence of CFP, no data relative to the abundance of benthic dinoflagellates are available in those two islands. Such ecological studies are now needed, focusing not only on Gambierdiscus species, but also on other potentially toxic genera, such as Ostreopsis Schmidt, Prorocentrum, Coolia, and Amphidinium.

Species of Ostreopsis and Gambierdiscus are particularly harmful to human populations and interest in studying these dinoflagellates has revived since the discovery of cryptic species (Richlen et al. 2008, Parsons et al. 2012, Nishimura et al. 2013, Penna et al. 2014). Ostreopsis siamensis Schmidt and Gambierdiscus toxicus Adachi et Fukuyo are the type species generally described for these genera. Over several years, the observations of morphological features by light microscopy have led to misidentifications (Litaker et al. 2009, Parsons et al. 2012). By using more recent molecular techniques and scanning electron microscopy (SEM) observations, more than a dozen Ostreopsis and Gambierdiscus species have been identified, and several of them are known to be toxic (Litaker et al. 2010, Accoroni et al. 2016, Rhodes et al. 2017). Using SEM and molecular tools proved to be useful and mandatory in studying the distribution, the diversity and the description of benthic dinoflagellates. However, such techniques are time-consuming and not compatible with large-scale ecological studies involving a large number of samples. On the other hand, the use of quantitative polymerase chain reaction (qPCR) seems promising for ecological studies (Smith et al. 2017) but needs to be improved and specific primers need to be designed for all the species potentially present.

In the framework of a large program aiming to study the diversity, ecology and impact of toxic benthic dinoflagellates in the Lesser Antilles (Guadeloupe and Martinique islands), the first steps, developed for this work, were (i) to describe the distribution and abundances of benthic dinoflagellates at the genus level and (ii) to identify potential affinities between ecological variables and biotic substrates hosting specific harmful dinoflagellate genera. 


\section{Materials and methods}

\section{Sampling}

Samples were collected between 26 January and 15 February 2014 in the Lesser Antilles, off the Caribbean and Atlantic coasts of Guadeloupe (20 stations) and Martinique (six stations) islands (Figure 1). The northern part of Martinique was not explored due to harsh environmental conditions (swell, steep coast) which made sampling difficult. At each station, macrophyte species with the highest spatial coverage were collected by snorkeling (Table 1 ).

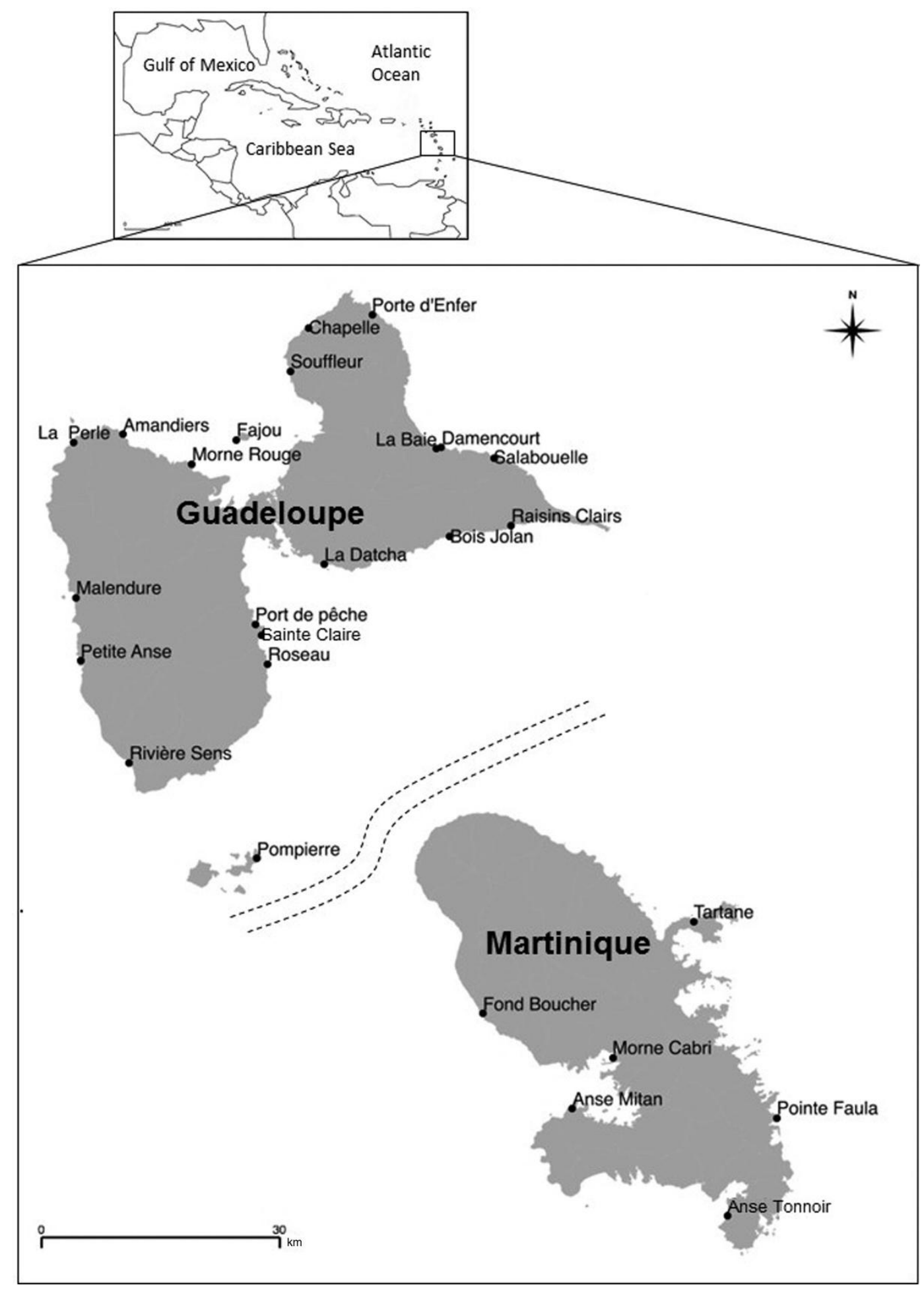


Figure 1: Map of Guadeloupe and Martinique with sampling sites. Dominique is not shown between islands.

Macrophytes were sampled referring to the protocol used to evaluate the abundance of Ostreopsis cf. ovata Fukuyo in the Mediterranean Sea (Cohu et al. 2011, 2013). All macrophytes were collected with care to avoid the loss of epiphytic cells at a water depth varying between 0.5 and $3 \mathrm{~m}$. Macrophytes were sampled with their surrounding seawater in 250-ml plastic flasks and immediately fixed with acidic Lugol $(1 \% \mathrm{vol} / \mathrm{vol})$. Each macrophyte was vigorously shaken during $10 \mathrm{~s}$ and rinsed twice with $100 \mathrm{ml}$ of $0.2-(\mathrm{m}$ filtered seawater to collect a maximum of epiphytic dinoflagellates. The macroalgal biomass was separated from the seawater sample by using a 500 (m-meshed sieve (Retsch@, $\emptyset 100 \mathrm{~mm})$. The biomass was then dried with absorbent paper and weighed (OHAUSC), Adventurer Pro Precision Balance, $\pm 0.1 \mathrm{~g}$ ) to estimate the fresh weight. A total of 161 samples were collected and analyzed.

Table 1: Locations of sampling stations and number of samples of Ulvophyceae, Phaeophyceae, Florideophyceae and seagrasses collected in Guadeloupe and Martinique.

\begin{tabular}{|c|c|c|c|c|c|c|c|}
\hline Sites & Orientation & Latitude & Longitude & Ulvophyceae & Phaeophyceae & Florideophyceae & Seagrasses \\
\hline \multicolumn{8}{|l|}{ Guadeloupe } \\
\hline Souffleur & Caribbean & $16^{\circ} 25^{\prime} 22.7^{\prime \prime} \mathrm{N}$ & $61^{\circ} 32^{\prime} 00.2^{\prime \prime} \mathrm{W}$ & 0 & 5 & 3 & 2 \\
\hline Chapelle & Caribbean & $16^{\circ} 28^{\prime} 17.9^{\prime \prime} \mathrm{N}$ & $61^{\circ} 30^{\prime} 46.2^{\prime \prime} \mathrm{W}$ & 2 & 4 & 3 & 0 \\
\hline Porte d'Enfer & Atlantic & $16^{\circ} 29^{\prime} 11.8^{\prime \prime} \mathrm{N}$ & $61^{\circ} 26^{\prime} 29.9^{\prime \prime} \mathrm{W}$ & 4 & 2 & 2 & 0 \\
\hline Damencourt & Atlantic & $16^{\circ} 20^{\prime} 13.5^{\prime \prime} \mathrm{N}$ & $61^{\circ} 21^{\prime} 48.9^{\prime \prime} \mathrm{W}$ & 0 & 4 & 1 & 0 \\
\hline La Baie & Atlantic & $16^{\circ} 20^{\prime} 07.0^{\prime \prime} \mathrm{N}$ & $61^{\circ} 22^{\prime} 02.4^{\prime \prime} \mathrm{W}$ & 2 & 0 & 2 & 0 \\
\hline Salabouelle & Atlantic & $16^{\circ} 19^{\prime} 30.3^{\prime \prime} \mathrm{N}$ & $61^{\circ} 18^{\prime} 14.4^{\prime \prime} \mathrm{W}$ & 2 & 2 & 1 & 1 \\
\hline Raisins Clairs & Atlantic & $16^{\circ} 14^{\prime} 54.9^{\prime \prime} \mathrm{N}$ & $61^{\circ} 17^{\prime} 02.9^{\prime \prime} \mathrm{W}$ & 2 & 6 & 3 & 1 \\
\hline Bois Jolan & Atlantic & $16^{\circ} 14^{\prime} 08.2^{\prime \prime} \mathrm{N}$ & $61^{\circ} 21^{\prime} 11.7^{\prime \prime} \mathrm{W}$ & 5 & 0 & 2 & 2 \\
\hline La Datcha & Atlantic & $16^{\circ} 12^{\prime} 17.3^{\prime \prime} \mathrm{N}$ & $61^{\circ} 29^{\prime} 41.9^{\prime \prime} \mathrm{W}$ & 0 & 1 & 3 & 2 \\
\hline Port de pêche & Atlantic & $16^{\circ} 08^{\prime} 14.1^{\prime \prime} \mathrm{N}$ & $61^{\circ} 34^{\prime} 23.7^{\prime \prime} \mathrm{W}$ & 1 & 0 & 1 & 0 \\
\hline Sainte Claire & Atlantic & $16^{\circ} 07^{\prime} 29.0^{\prime \prime} \mathrm{N}$ & $61^{\circ} 33^{\prime} 59.0^{\prime \prime} \mathrm{W}$ & 2 & 0 & 0 & 3 \\
\hline Roseau & Atlantic & $16^{\circ} 05^{\prime} 32.3^{\prime \prime} \mathrm{N}$ & $61^{\circ} 33^{\prime} 32.3^{\prime \prime} \mathrm{W}$ & 5 & 0 & 1 & 1 \\
\hline Pompierre & Atlantic & $15^{\circ} 52^{\prime} 20.1^{\prime \prime} \mathrm{N}$ & $61^{\circ} 34^{\prime} 16.8^{\prime \prime} \mathrm{W}$ & 1 & 0 & 1 & 1 \\
\hline Rivière Sens & Caribbean & $15^{\circ} 58^{\prime} 50.4^{\prime \prime} \mathrm{N}$ & $61^{\circ} 42^{\prime} 55.1^{\prime \prime} \mathrm{W}$ & 0 & 1 & 2 & 0 \\
\hline Petite Anse & Caribbean & $16^{\circ} 05^{\prime} 43.1^{\prime \prime} \mathrm{N}$ & $61^{\circ} 46^{\prime} 14.7^{\prime \prime} \mathrm{W}$ & 0 & 1 & 0 & 1 \\
\hline Malendure & Caribbean & $16^{\circ} 07^{\prime} 50.2^{\prime \prime} \mathrm{N}$ & $61^{\circ} 46^{\prime} 11.6^{\prime \prime} \mathrm{W}$ & 1 & 1 & 2 & 1 \\
\hline La Perle & Caribbean & $16^{\circ} 20^{\prime} 33.1^{\prime \prime} \mathrm{N}$ & $61^{\circ} 46^{\prime} 40.0^{\prime \prime} \mathrm{W}$ & 0 & 2 & 2 & 0 \\
\hline Amandiers & Mangrove & $16^{\circ} 21^{\prime} 04.3^{\prime \prime} \mathrm{N}$ & $61^{\circ} 43^{\prime} 21.4^{\prime \prime} \mathrm{W}$ & 6 & 0 & 2 & 1 \\
\hline Morne Rouge & Mangrove & $16^{\circ} 19^{\prime} 05.5^{\prime \prime} \mathrm{N}$ & $61^{\circ} 38^{\prime} 40.6^{\prime \prime} \mathrm{W}$ & 1 & 0 & 0 & 0 \\
\hline Fajou & Mangrove & $16^{\circ} 20^{\prime} 44.4^{\prime \prime} \mathrm{N}$ & $61^{\circ} 35^{\prime} 39.5^{\prime \prime} \mathrm{W}$ & 0 & 1 & 0 & 0 \\
\hline \multicolumn{8}{|l|}{ Martinique } \\
\hline Tartane & Atlantic & $14^{\circ} 45^{\prime} 30.0^{\prime \prime} \mathrm{N}$ & $60^{\circ} 55^{\prime} 15.8^{\prime \prime} \mathrm{W}$ & 4 & 0 & 1 & 1 \\
\hline Pointe Faula & Atlantic & $14^{\circ} 32^{\prime} 27.6^{\prime \prime} \mathrm{N}$ & $60^{\circ} 49^{\prime} 43.7^{\prime \prime} \mathrm{W}$ & 6 & 4 & 0 & 3 \\
\hline Anse Tonnoir & Caribbean & $14^{\circ} 25^{\prime} 59.0^{\prime \prime} \mathrm{N}$ & $60^{\circ} 53^{\prime} 00.0^{\prime \prime} \mathrm{W}$ & 4 & 1 & 3 & 1 \\
\hline Anse Mitan & Caribbean & $14^{\circ} 33^{\prime} 03.6^{\prime \prime} \mathrm{N}$ & $61^{\circ} 03^{\prime} 17.0^{\prime \prime} \mathrm{W}$ & 4 & 2 & 4 & 0 \\
\hline Morne Cabri & Mangrove & $14^{\circ} 36^{\prime} 20.5^{\prime \prime} \mathrm{N}$ & $61^{\circ} 01^{\prime} 17.8^{\prime \prime} \mathrm{W}$ & 0 & 1 & 0 & 1 \\
\hline Fond Boucher & Caribbean & $14^{\circ} 39^{\prime} 22.6^{\prime \prime} \mathrm{N}$ & $61^{\circ} 09^{\prime} 15.6^{\prime \prime} \mathrm{W}$ & 1 & 4 & 3 & 2 \\
\hline
\end{tabular}

\section{Dinoflagellate cell abundances}

Epiphytic cell abundance measurements (cells per gram of fresh macrophyte weight) were performed by cell counts using 1-ml Sedgewick-Rafter cells(C) with a standard light microscope in brightfield optics at 20 - magnification (Zeiss, Axio Lab.A1). The number of cells per gram of fresh weight (cells g-1) was calculated considering the amount of water present for each sample and the weight of the fresh macrophyte. Cell counts were undertaken for Ostreopsis, Prorocentrum, Gambierdiscus, Coolia and Amphidinium genera. Gambierdiscus and Fukuyoa Gómez, Qiu, Lopes et Lin were difficult to differentiate by light microscopy, therefore the latter when present, were counted as Gambierdiscus. The genus Sinophysis was not considered in this study.

\section{Phylogenetic and morphological categories of macrophytes}

Macrophytes were identified to the genus level (Table 2). When the genus determination was uncertain, the word "complex" was added. Macrophytes were classified into Ulvophyceae, Phaeophyceae, 
Florideophyceae and seagrass groups in order to evaluate a potential relationship between benthic dinoflagellates and these phylogenetic groups of macrophytes. Morphological characteristics of macrophytes were described as blade-, cylindricalor non-ramified.

\section{Environmental parameters}

Sampling sites were classified into three categories: Atlantic coast, Caribbean coast, and mangrove environment.

Table 2: Number of samples collected for each macrophyte genus in Guadeloupe and Martinique.

\begin{tabular}{|c|c|c|c|}
\hline & Guadeloupe & Martinique & Morphology \\
\hline Ulvophyceae & 34 & 19 & \\
\hline Bryopsis spp. & 3 & 1 & CR \\
\hline Caulerpa spp. & 11 & 10 & $\mathrm{BR} / \mathrm{CR}$ \\
\hline Chaetomorpha spp. & 2 & 2 & NR \\
\hline Halimeda spp. & 6 & 0 & BR \\
\hline Penicillus spp. & 2 & 2 & $C R$ \\
\hline Udotea spp. & 3 & 4 & NR \\
\hline Ulva spp. & 5 & 0 & NR \\
\hline Valonia spp. & 2 & 0 & CR \\
\hline Phaeophyceae & 31 & 12 & \\
\hline Dictyopteris spp. & 1 & 0 & CR \\
\hline Dictyota spp. & 18 & 8 & $\mathrm{BR}$ \\
\hline Padina spp. & 5 & 3 & NR \\
\hline Sargassum spp. & 6 & 1 & $B R$ \\
\hline Turbinaria spp. & 1 & 0 & BR \\
\hline Florideophyceae & 30 & 10 & \\
\hline Acanthophora spp. & 6 & 5 & BR \\
\hline Amphiroa spp. & 2 & 0 & CR \\
\hline Asparagopsis spp. & 1 & 0 & CR \\
\hline Bryothamnion spp. & 3 & 0 & BR \\
\hline Ceramium spp. & 2 & 1 & CR \\
\hline $\begin{array}{l}\text { Digenea simplex } \\
\text { (Wulfen) C. Agardh }\end{array}$ & 1 & 0 & CR \\
\hline Galaxaura complex & 11 & 2 & CR \\
\hline Jania spp. & 1 & 1 & CR \\
\hline Laurencia complex & 1 & 0 & BR \\
\hline Liagora complex & 0 & 1 & CR \\
\hline $\begin{array}{l}\text { Palisada perforata } \\
\text { (Bory) Nam }\end{array}$ & 2 & 0 & CR \\
\hline Seagrass & 16 & 8 & \\
\hline Halodule spp. & 0 & 1 & NR \\
\hline Halophila spp. & 2 & 4 & NR \\
\hline $\begin{array}{l}\text { Syringodium filiforme } \\
\text { Kützing }\end{array}$ & 5 & 2 & NR \\
\hline $\begin{array}{l}\text { Thalassia testudinum } \\
\text { König }\end{array}$ & 9 & 1 & NR \\
\hline
\end{tabular}

The thallus morphology is indicated as follows: NR, Non-ramified; $C R$, cylindrical-ramified; BR, blade-ramified.

The orientation of the bays was determined by a perpendicular line passing through the bottom of the bay and using the four cardinal points. The slope of the continental shelf (the zone where macrophytes were collected) of each site was estimated and classified in three categories: low $\left(<10^{\circ}\right)$, average (between $10^{\circ}$ and $30^{\circ}$ ) and strong $\left(>30^{\circ}\right)$ slope. The official National Institute of Geography (http://www.ign.fr/, last visit: 28 August 2017) provided the necessary data to determine the freshwater input as close as 200 $\mathrm{m}$ from each sampling site. Water transparency was also noted qualitatively and sampling sites were distinguished in two categories: clear and turbid waters. 
Another factor considered in this study was the presence of chlordecone, a toxic, persistent, organochlorine insecticide used between 1972 and 1993 in French Caribbean islands. Driven by the water cycle, this terrestrial pollutant is progressively transferred to aquatic ecosystems (Coat et al. 2011). In a regional ordinance (2005; http://bit.ly/2uCCVs8, last visit: 26 August 2017) which prohibits fishing, consumption and marketing of organisms originating from Guadeloupe and Martinique, the littoral is divided into three categories: area with a total fishing ban, area with a fishing ban only on some species, and a no ban area. Sampling sites in this present study were localized within these three different areas linked to chlordecone levels.

\section{Data analysis}

The geographical mapping of benthic dinoflagellate abundances was made by using Qgis 2.10 Pisa software (C) and statistical analyses were performed with XLSTAT software(C). Cell abundances of dinoflagellates in Guadeloupe and Martinique did not follow a normal distribution, therefore nonparametric statistical analyses were used. Kruskal-Wallis test was used to compare the distribution of each dinoflagellate genus (i) between Guadeloupe and Martinique, (ii) according to macrophyte hosts of different groups and morphology, and (iii) according to sampling sites and environmental parameters. All descriptive analyses are presented as the mean. Multiple pairwise comparisons using the Conover-Iman Test were performed after Kruskal-Wallis test to compare the results from each treatment.

\section{Results}

\section{Macrophytes}

A total of 111 macrophyte samples were collected in Guadeloupe and 49 in Martinique (Table 2). In both islands, the Ulvophyceae was the dominant host group, followed by the Phaeophyceae, Florideophyceae, and seagrasses. Blade-ramified macrophytes dominated the seagrass group in both islands. In Guadeloupe, seagrasses were more cylindrically ramified than non-ramified, in contrast to Martinique. Twenty-six macrophyte genera were identified in Guadeloupe and 17 in Martinique. The macrophyte diversity was greater within the Florideophyceae and Ulvophyceae groups for both islands compared to seagrasses and Phaeophyceae. Phaeophyceae were more diversified than seagrasses in Guadeloupe and the opposite was observed in Martinique.

In each group of macrophytes, one genus dominated widely. Ulvophyceae were dominated by the genus Caulerpa Lamouroux, Phaeophyceae by the genus Dictyota Lamouroux and Florideophyceae by the Galaxaura complex. For the seagrass group, Thalassia Banks ex König was the dominant genus in Guadeloupe while Halophila Du Petit-Thouars predominated in Martinique.

\section{Cell abundances of benthic dinoflagellates}

Abundances of benthic dinoflagellates in Guadeloupe ranged between 0 and 55,910 cells g-1 and were one order of magnitude higher than in Martinique $(\mathrm{p}=0.018)$. The genus Ostreopsis was dominant in both islands. Cell abundances of Ostreopsis $(\mathrm{p}<0.001)$ and Coolia $(\mathrm{p}=0.001)$ were significantly different between the two islands, while Prorocentrum, Gambierdiscus and Amphidinium abundances were similar ( $>$ > 0.05; Table 3). 
Table 3: Results of Kruskal-Wallis tests comparing abundance of five potentially toxic benthic dinoflagellate genera between Guadeloupe and Martinique.

\begin{tabular}{lr}
\hline & p-Value \\
\hline Ostreopsis & $<0.001^{\mathrm{a}}$ \\
Prorocentrum & 0.327 \\
Gambierdiscus & 0.368 \\
Amphidinium & 0.115 \\
Coolia & $0.001^{\mathrm{a}}$ \\
Total & $0.018^{\mathrm{a}}$ \\
\hline
\end{tabular}

andicates $\mathrm{p}$-value significant at $\alpha=0.05$.

In Guadeloupe, abundances of Ostreopsis averaged 2403 cells g ${ }^{-1}$, Prorocentrum averaged 1177 cells g $^{-1}$,

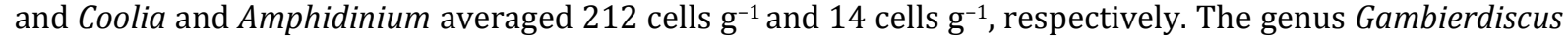
was estimated with an average abundance of 6 cells $\mathrm{g}^{-1}$ overall macrophytes. Significant positive correlations were found between Ostreopsis, Prorocentrum, Amphidinium and Coolia genera (Table 4).

Table 4: Coefficient $r_{\mathrm{s}}$ of Spearman rank correlation for abundances among five potentially toxic benthic dinoflagellates in Guadeloupe and Martinique islands.

\begin{tabular}{|c|c|c|c|c|}
\hline & Prorocentrum & Gambierdiscus & Coolia & Amphidinium \\
\hline \multicolumn{5}{|l|}{ Guadeloupe } \\
\hline Ostreopsis & $0.583^{c}$ & $<0.001$ & $0.260^{c}$ & $0.081^{\mathrm{a}}$ \\
\hline Prorocentrum & & 0.025 & $0.253^{c}$ & $0.120^{\mathrm{b}}$ \\
\hline Gambierdiscus & & & 0.017 & $<0.001$ \\
\hline Coolia & & & & $0.191^{c}$ \\
\hline \multicolumn{5}{|l|}{ Martinique } \\
\hline Ostreopsis & 0.036 & $0.090^{\mathrm{a}}$ & 0.031 & 0.003 \\
\hline Prorocentrum & & 0.006 & 0.009 & 0.023 \\
\hline Gambierdiscus & & & 0.018 & 0.014 \\
\hline Coolia & & & & 0.002 \\
\hline
\end{tabular}

${ }^{\mathrm{a} p}<0.05,{ }^{\mathrm{b}} \mathrm{p}<0.001,{ }^{\mathrm{c}} \mathrm{p}<0.0001$.

In Martinique, Ostreopsis abundances reached an average of 260 cells g $^{-1}$, Prorocentrum reached 247 cells $\mathrm{g}^{-1}$, while Coolia and Amphidinium averaged 10 cells g ${ }^{-1}$ and 4 cells $\mathrm{g}^{-1}$, respectively. The abundance of the genus Gambierdiscus was estimated with an average of 6 cells $\mathrm{g}^{-1}$ overall macrophytes. A significant positive correlation existed between Ostreopsis and Gambierdiscus (Table 4).

In Guadeloupe, the highest average abundances of potentially toxic benthic dinoflagellates were found at

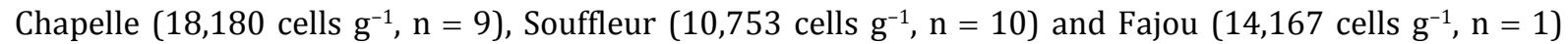
sampling sites (ConoverIman Test, $\mathrm{p}<0.001$, Figure 2). The genus Ostreopsis was found with the highest abundances $(\mathrm{p}<0.001)$ at these three sites, varying between 3408 and 14,751 cells $\mathrm{g}^{-1}$. Souffleur was the site with the highest abundance of Prorocentrum (5823 cells $\mathrm{g}^{-1}, \mathrm{n}=10, \mathrm{p}<0.001$ ). Rivière Sens, Pompierre and Morne Rouge had the highest abundances of Gambierdiscus ( $\mathrm{p}<0.001$ ), ranging between 54 and 105 cells g-1 (Figure 3 ).

In Martinique, abundances of benthic dinoflagellates were significantly higher at Fond Boucher (1134 cells $\mathrm{g}^{-1}$ ) and Morne Cabri (2543 cells $\mathrm{g}^{-1}$ ) compared to other sites. The highest cell abundance of Ostreopsis (1049 cells $\mathrm{g}^{-1}, \mathrm{p}=0.001$ ) was recorded in Fond Boucher, which significantly differed from the other sampling sites. Cell abundances of Gambierdiscus, Amphidinium, and Coolia were comparable between all sampling sites in Martinique, with the lowest abundances of benthic dinoflagellates recorded at Tartane. 


\section{Relationships between benthic dinoflagellates and macrophytes}

Macrophyte groups hosted different abundances of potentially toxic benthic dinoflagellates. In Guadeloupe, the total cell abundances of benthic dinoflagellates were significantly higher on seagrasses (5098 cells $\mathrm{g}^{-1}$ ) and on Phaeophyceae (6343 cells $\mathrm{g}^{-1}$ ), than on Ulvophyceae

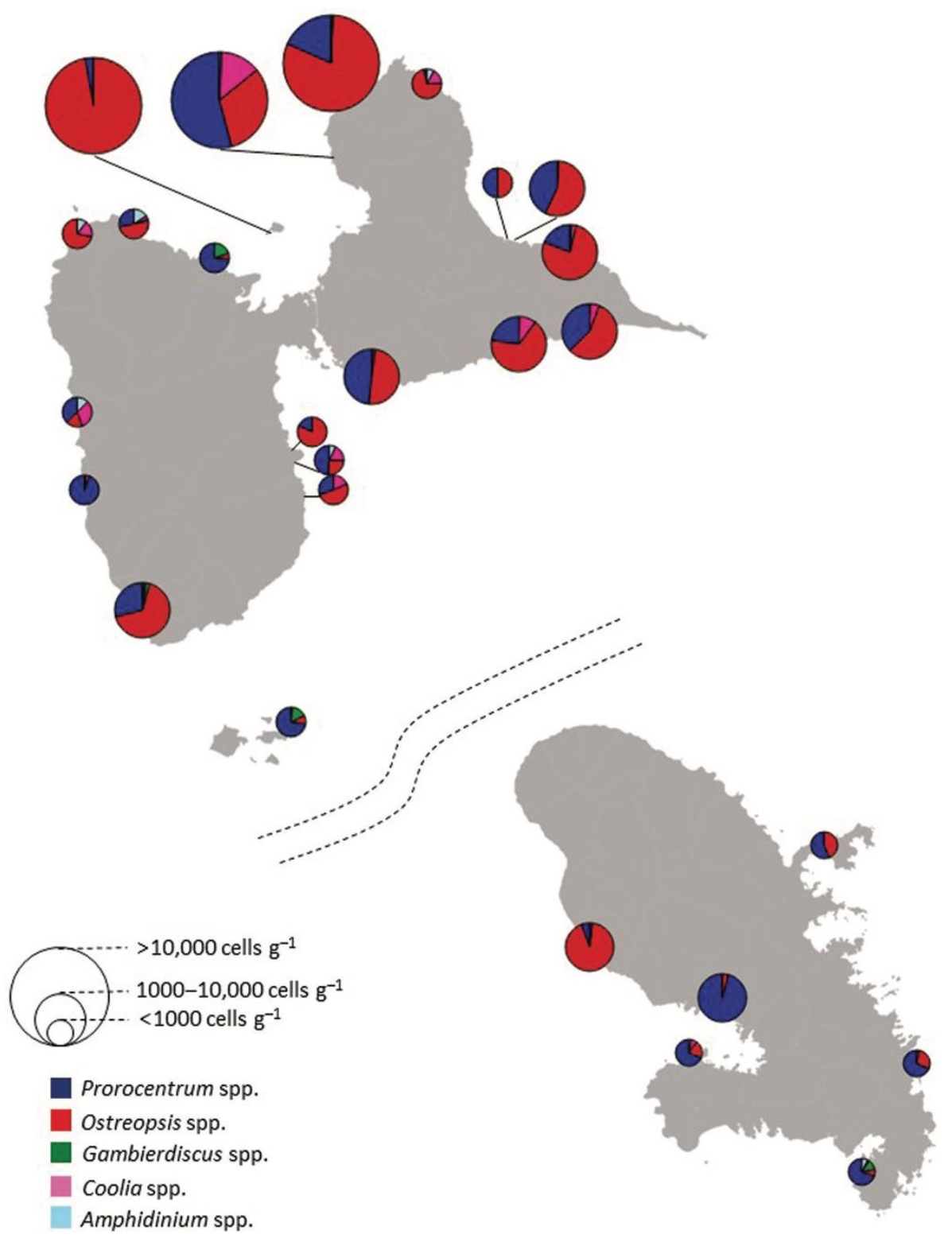

Figure 2: Average abundances (cells g ${ }^{-1}$ ) of five potentially toxic benthic dinoflagellates in Guadeloupe (above) and Martinique (below).

(424 cells $\mathrm{g}^{-1}, \mathrm{p}<0.001$; Figure 4). Ostreopsis and Coolia abundances were found with highest values on Phaeophyceae ( $\mathrm{p}<0.001)$ whilst the genus Prorocentrum was found with the highest abundances on several groups of macrophytes such as Phaeophyceae, seagrasses, and Florideophyceae $(\mathrm{p}<0.001)$. Amphidinium and Gambierdiscus cell abundances reached similar levels on all macrophyte groups ( $\mathrm{p}>$ 0.05; Figure 5). The total abundance of dinoflagellates was not related to the morphology of the macrophytes. Indeed, no significant differences were found between the abundance values for benthic dinoflagellates on different morphologies of macrophytes $(p=0.074)$. However, when considering the different dinoflagellate 
genera independently, the results showed that Prorocentrum and Ostreopsis had the highest cell abundances on the blade-ramified substratum ( $p<0.04$; Figure $5 \mathrm{~A})$.

In Martinique, the highest abundance of dinoflagellates was found on Phaeophyceae ( 975 cells g$^{-1}$ ) and Florideophyceae (547 cells g-1), while the lowest abundance was reported on Ulvophyceae (151 cells g-1 $\mathrm{p}$ $=0.001$; Figure 6). Ostreopsis had the highest cell abundances on the Phaeophyceae with, on average, 712 cells $\mathrm{g}^{-1}(\mathrm{p}<0.0003)$. Prorocentrum, Gambierdiscus, Amphidinium and Coolia had similar abundance levels on the different macrophyte groups (Figure 5B). Blade-ramified macrophytes hosted significantly more potentially toxic benthic

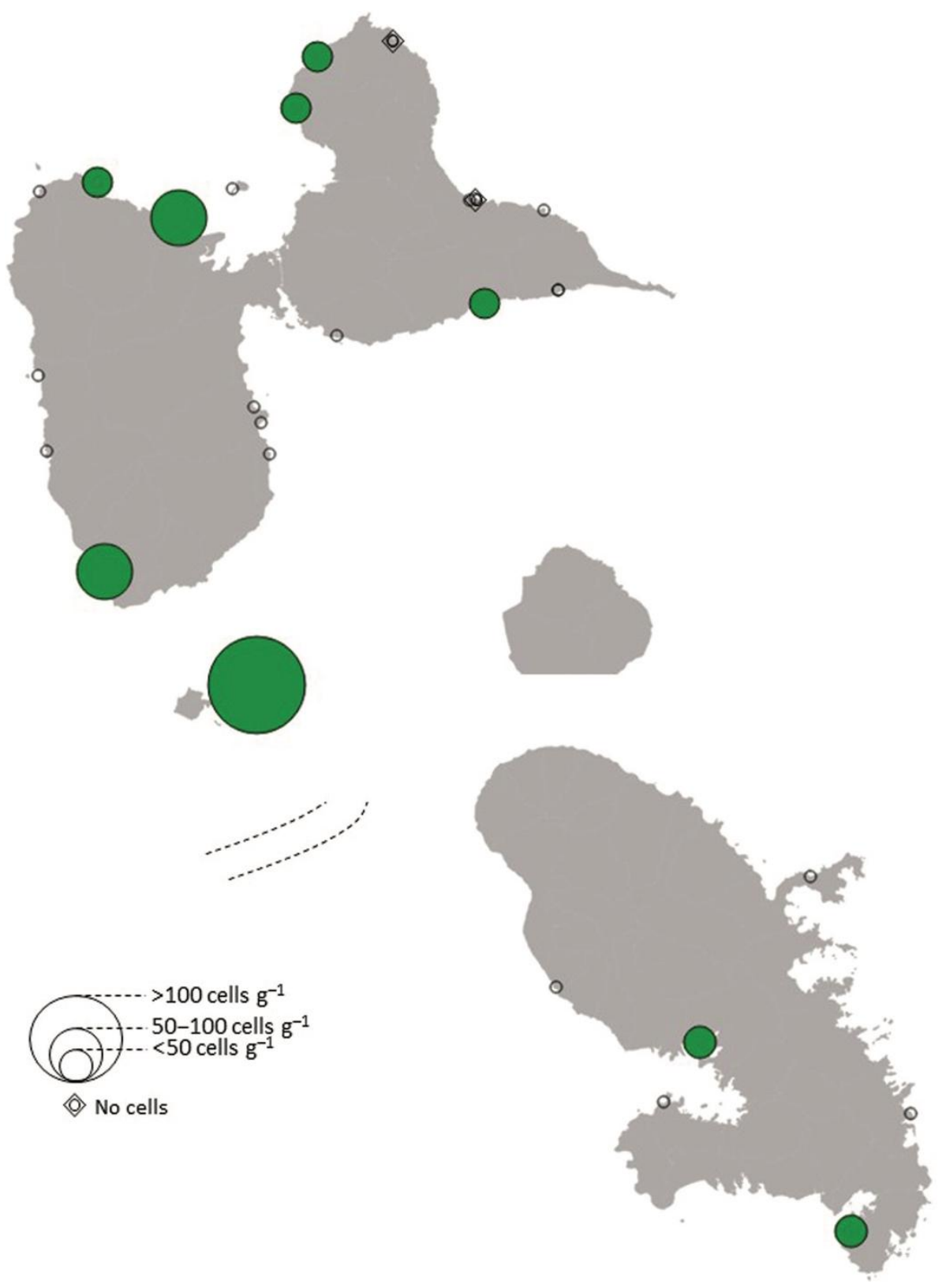

Figure 3: Average abundances (cells $\mathrm{g}^{-1}$ ) of the benthic dinoflagellate Gambierdiscus in Guadeloupe (above) and Martinique (below).

dinoflagellates compared to cylindrical and non-ramified macrophytes $(\mathrm{p}=0.012$; Figure $5 \mathrm{~B})$. Ostreopsis was found with higher cell abundances on blade-ramified macrophytes than on non-ramified macrophytes ( $\mathrm{p}=0.015)$.

\section{Relationship between benthic dinoflagellates and ecological parameters}


In Guadeloupe, potentially toxic benthic dinoflagellates were more abundant on the Caribbean coast (8469 cells g-1)

than on the Atlantic coast (1918 cells $\mathrm{g}^{-1}$ ) or in mangrove environments (1371 cells $\mathrm{g}^{-1} ; \mathrm{p}=0.001$; Figure 2). Sampling sites with turbid water presented lower abundances of benthic dinoflagellates ( 797 cells $\mathrm{g}^{-1}$ ) than sites with clear water $\left(5718\right.$ cells g $^{-1} ; \mathrm{p}=0.009$ ). The identified zones contaminated by chlordecone

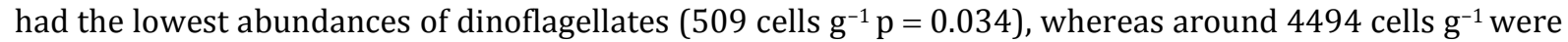
found in areas not contaminated. The occurrence of freshwater inflow within $200 \mathrm{~m}$ of the sampling site did not affect the abundance of epibenthic dinoflagellates $(p>0.934)$. In Martinique, no environmental parameters considered in the present study affected the abundance of benthic dinoflagellates $(p>0.05)$.

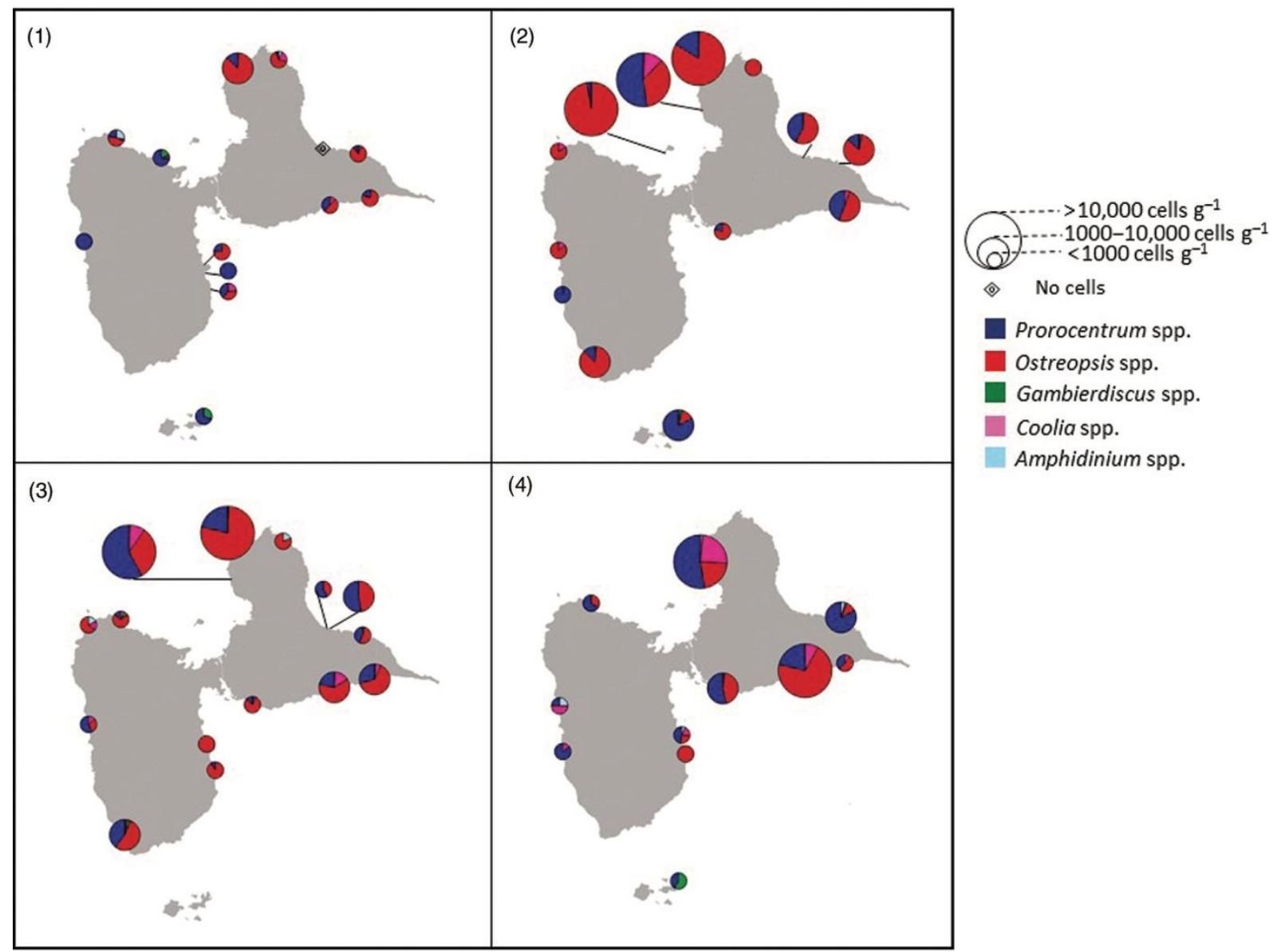

Figure 4: Average abundances (cells g ${ }^{-1}$ ) of five potentially toxic benthic dinoflagellates on (1) Ulvophyceae, (2) Phaeophyceae, (3) Florideophyceae and (4) Seagrasses in Guadeloupe. No mark appears when a macrophyte group was not found at a station.

\section{Discussion}

This work is the first exploratory study focusing on the distribution and abundance of potentially toxic benthic dinoflagellates in Guadeloupe and Martinique. Species of the genera Ostreopsis, Prorocentrum, Gambierdiscus, Coolia, and Amphidinium were identified in all sampling sites. Differences in abundance and distribution emerged between both islands. Results also showed that dinoflagellate genera had preferences for certain biological substrates as well as relationships with environmental parameters. Similar studies have been undertaken in other Caribbean islands, but cell abundances were not always expressed in the same units (Carlson and Tindall 1985) and differed considering the sampling period and the macrophytes used as hosts. 



\section{Dinoflagellate abundances and affinities with macrophytes}

Ostreopsis and Prorocentrum were the most abundant genera of potentially toxic epibenthic dinoflagellates in Guadeloupe and Martinique. Cell abundances of Ostreopsis were comparable to previous studies undertaken in the Caribbean basin (Ballantine et al. 1985, 1988, Okolodkov et al. 2014). In this study, Ostreopsis abundances varied between 963 and 5677 cells $\mathrm{g}^{-1}$ on the same macrophyte in Guadeloupe and in Martinique. A previous study carried out in Cuba, between January 2000 and 2002, showed that the genus Prorocentrum reached an average abundance of 50 cells $\mathrm{g}^{-1}$ for several combined macrophytes (Delgado et al. 2005), which is respectively, 23 to 5 times less than the cell abundances recorded in Guadeloupe and Martinique.

\begin{tabular}{|c|c|c|c|c|c|}
\hline \multicolumn{6}{|l|}{ (A) Guadeloupe } \\
\hline Genera & Pairwise comparisons & p-Value & Genera & Pairwise comparisons & $\mathrm{p}$-Value \\
\hline Ostreopsis & 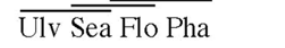 & p $<0.0001$ & Ostreopsis & $\overline{\text { NR CR }}$ BR & $p=0.002$ \\
\hline Prorocentrum & Ulv $\overline{\text { Flo Sea Pha }}$ & $p<0.0001$ & Prorocentrum & $\overline{\mathrm{CR} \mathrm{NR} B R}$ & $p=0.037$ \\
\hline Gambierdiscus & $\overline{\text { Ulv Sea Pha Flo }}$ & $p=0.211$ & Gambierdiscus & $\overline{\mathrm{NR} B R} \mathrm{CR}$ & $\mathrm{p}=0.142$ \\
\hline Amphidinium & $\overline{\text { Ulv Pha Sea Flo }}$ & $\mathrm{p}=0.182$ & Amphidinium & $\overline{\text { NR CR BR }}$ & $\mathrm{p}=0.298$ \\
\hline Coolia & $\overline{\text { Ulv Sea Flo Pha }}$ & $p=0.029$ & Coolia & $\overline{\mathrm{CR} N R \mathrm{BR}}$ & $p=0.466$ \\
\hline Total & $\overline{\text { Ulv Flo Sea Pha }}$ & $p=0.0001$ & Total & $\overline{\text { CR NR BR }}$ & $\mathrm{p}=0.074$ \\
\hline \multicolumn{6}{|l|}{ (B) Martinique } \\
\hline Genera & Pairwise comparisons & p-Value & Genera & Pairwise comparisons & p-Value \\
\hline Ostreopsis & 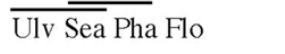 & $\mathrm{p}<0.003$ & Ostreopsis & $\overline{\mathrm{NR} C \mathrm{CR}} \mathrm{BR}$ & $\mathrm{p}=0.002$ \\
\hline Prorocentrum & $\overline{\text { Ulv Sea Flo Pha }}$ & $\mathrm{p}=0.18$ & Prorocentrum & $\overline{\mathrm{CR} \mathrm{NR} B R}$ & $\mathbf{p}=\mathbf{0 . 0 3 7}$ \\
\hline Gambierdiscus & $\overline{\text { Ulv Pha Sea Flo }}$ & $\mathrm{p}=0.140$ & Gambierdiscus & $\overline{\text { NR BR CR }}$ & $\mathrm{p}=0.423$ \\
\hline Amphidinium & Pha Sea Ulv Flo & $\mathrm{p}=0.288$ & Amphidinium & $\overline{\text { NR BR CR }}$ & $\mathrm{p}=0.328$ \\
\hline Coolia & $\overline{\text { Sea Ulv Pha Flo }}$ & $\mathrm{p}=0.0326$ & Coolia & $\overline{\mathrm{BR} \text { CR NR }}$ & $\mathrm{p}=0.112$ \\
\hline Total & $\overline{\text { Ulv Sea Flo Pha }}$ & $p=0.001$ & Total & $\overline{\mathrm{CR} \mathrm{NR}} \mathrm{BR}$ & $p=0.012$ \\
\hline
\end{tabular}

Figure 5: Multiple pairwise comparisons using the Conover-Iman procedure and p-value of Kruskal-Wallis test $(\alpha=0.05)$ for comparison of phylogenetic macrophyte groups (left) and macrophyte morphology groups (right) for each genus of the five potentially toxic benthic dinoflagellates in $(A)$ Guadeloupe $(n=111)$ and $(B)$ Martinique $(n=50)$. Ulv, Ulvophyceae; Sea, Seagrasses; Flo, Florideophyceae; Pha, Phaeophyceae; NR, non-ramified; CR, cylindrical-ramified; BR, bladeramified. Significant p-values are in bold. The groups and morphology of macrophytes are listed in order of benthic dinoflagellates mean abundances values, with lowest on left and highest on right.

In Guadeloupe, Prorocentrum and Ostreopsis were identified on the same biological substrates and with the highest abundance values on blade-ramified macrophytes. Ostreopsis was found preferentially on Phaeophyceae alone, while Prorocentrum was found preferentially on Phaeophyceae, Florideophyceae, and seagrasses. In Martinique, Ostreopsis was found in high abundances on blade-ramified macrophytes and preferentially on Florideophyceae, while the abundance of Prorocentrum was not affected by macrophyte morphology. Affinities of Prorocentrum and Ostreopsis species for macrophytes differed in other Caribbean studies. In Cuba, Prorocentrum was preferentially observed on Phaeophyceae and Ulvophyceae (Delgado et al. 2005) while Ostreopsis did not demonstrate any preference for either host (Ballantine et al. 1985).

Average abundance values of Gambierdiscus were similar between Guadeloupe and Martinique, but 10 times lower than abundances reported from Puerto Rico (between 100 and 1250 cells g-1; Ballantine et al. 1988). Gambierdiscus seemed able to settle on all macrophytes and showed no preference for a specific group nor morphology, as was previously reported (Saint Martin et al. 1988). However in Cuba, 
Gambierdiscus prevailed on Phaeophyceae, Florideophyceae and then Ulvophyceae (Delgado et al. 2005), and in Puerto Rico, Dictyota was a better host than the seagrass Thalassia testudinum König (Ballantine et al. 1985).

In this study, Amphidinium and Coolia were present at very low cell abundances. Such results coincided with previous studies reporting low abundances during different sampling periods in the Gulf of Mexico (Okolodkov et al. 2007).

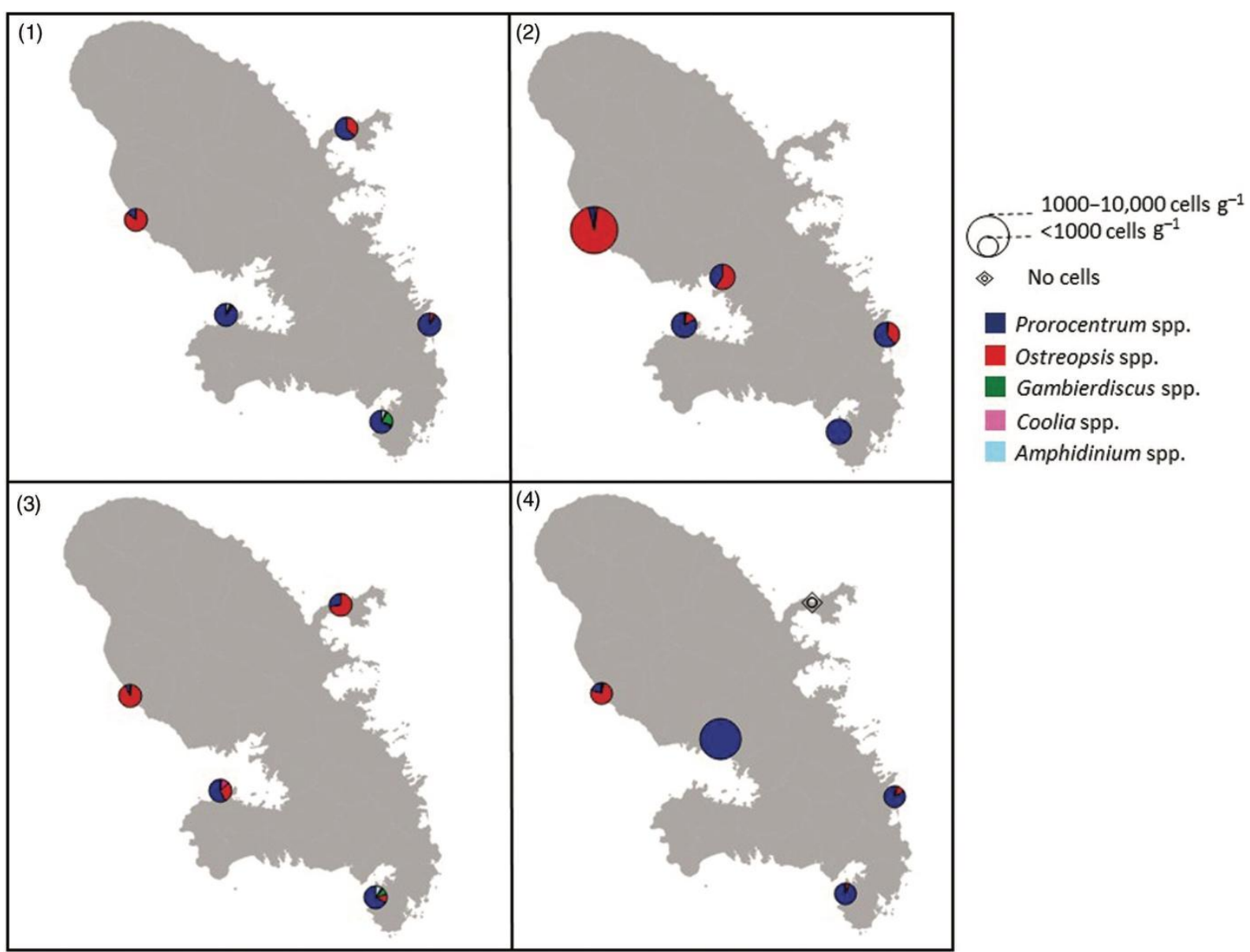

Figure 6: Average abundances (cells $\mathrm{g}^{-1}$ ) of five potentially toxic benthic dinoflagellates on (1) Ulvophyceae, (2) Phaeophyceae, (3) Florideophyceae and (4) Seagrasses in Martinique island.

\section{Dinoflagellate abundance and environmental variables}

In this study, benthic dinoflagellates were more abundant in Guadeloupe (particularly on the northern coast) than in Martinique. This pattern does not appear to be linked to temperature, as the maximum (September) and minimum (February) sea surface temperatures were similar between both islands (see maps of sea surface temperature across the Caribbean in Tester et al. 2010). Nevertheless, this pattern must be confirmed by seasonal variation studies. Different periodic patterns of benthic dinoflagellate abundance have already been highlighted in the Caribbean (Ballantine et al. 1985, Okolodkov et al. 2014), but the origin of those fluctuations varied and was not consistent (e.g. temperature, nutrient inputs, seasonal occurrence of main macrophytes). In Guadeloupe, benthic dinoflagellates were more abundant on the Caribbean coast than on the Atlantic coast and in mangroves.

The inflow of freshwater relatively close to each station (up to $200 \mathrm{~m}$ ) did not affect the total abundance of benthic dinoflagellates in Guadeloupe and Martinique.

As for marine areas exposed to chlordecone inputs, benthic dinoflagellates showed lower abundance levels in Guadeloupe sampling sites with a total fishing ban compared to sites without contamination, 
while this trend was not observed in Martinique, probably because the sampling sites were mainly outside the fishing banned areas.

\section{Ciguatera and Gambierdiscus}

The genus Gambierdiscus is the causal agent of CFP and the Caribbean has the second highest incidence rate in the world (Chinain et al. 2014). In this study, Gambierdiscus was found in Guadeloupe and Martinique with a strong spatial variability. This report of Gambierdiscus species in Guadeloupe and Martinique questions the local belief regarding the origin of ciguateric fish in those islands. Indeed, the great majority of inhabitants in both French islands believe that contaminated seafood products came from fishing activities in the northern Caribbean islands, where the incidence rates of CFP are much higher. For instance, the CFP incidence rates in Guadeloupe and Martinique are 0.3 and 0.2 per 10,000 inhabitants per year, respectively, while these rates reached an average of 34.4 and 58.6 per 10,000 inhabitants per year in Antigua/ Barbuda and Montserrat islands, respectively; these islands are just north of Guadeloupe (Tester et al. 2010). Results obtained in this study suggest that ciguateric fishes could be, at least partially, locally contaminated by Gambierdiscus toxins in Guadeloupe and Martinique.

This study also gives indications of potential sites for survey studies related to Gambierdiscus and ciguatera outbreaks. In Guadeloupe, among the four most important sites registered with ciguatoxic fishes between 2004 and 2008 (Anse Bertrand, Abymes, Désirade, and Pointe Noire; Rosine et al. 2008), only one location coincided with a sampling site hosting Gambierdiscus (Chapelle in Anse Bertrand City). It should be highlighted that, in the present study, Pompierre (Saintes islands, South West of Guadeloupe) hosted the highest abundance of Gambierdiscus and notably that this area was also an intensive fishing zone. Therefore, Guadeloupe should be recommended as part of a potential monitoring program for CFP. In Martinique Island, Anse Tonnoir (Sainte Anne City), Tartane (Trinité City) and Pointe Faula (Vauclin City) sampling sites could be potentially important sites since these are cities where sampling sites have already been reported by the Health Agency of Martinique to involve verified cases of CFP (Daudens et al. 2013, Daudens-Vaysse et al. 2015). Also, Anse Tonnoir in Sainte Anne City showed the highest abundances of Gambierdiscus. Those dinoflagellates were also found at Fond Boucher, but no recent CFP cases have been reported to the Health Agency at this location.

In conclusion, this study determined, for the first time, the abundance of several potentially toxic benthic dinoflagellates in the French West Indies, namely Martinique and Guadeloupe. Dinoflagellates were identified to the genus level using light microscopy in order to avoid species misidentification and to perform a very large number of cell counts. During the 2014 dry season, benthic dinoflagellates were one order of magnitude more abundant in Guadeloupe than in Martinique. Ostreopsis was the most abundant genus, followed by Prorocentrum, Coolia, Amphidinium, and Gambierdiscus. Macrophyte species, their morphologies, and their phylogenetic groups could influence dinoflagellate abundances growing on them. In Guadeloupe, a toxic and persistent organochlorine pesticide, chlordecone, had a strong negative effect on benthic dinoflagellate abundances.

The presence of Gambierdiscus in both islands supports the possible idea that local fish might be contaminated locally and could, at least in part, explain CFP in Guadeloupe and Martinique. This is especially relevant when ciguatoxic fish are known not to be large pelagic species similar to those found in more contaminated islands in the North. The present study, with associated local epidemiological data, can be used to determine several key sites which could be recommended to be studied in the framework of a CFP monitoring program.

This preliminary survey is of great importance since it allows scientists and health and marine management services in Guadeloupe and Martinique to select preferential sampling sites and to determine accurate biological substrates for sampling in order to study (1) the potential seasonal variation of potentially toxic benthic dinoflagellates, as well as (2) the morphogenetic profiles of the different identified species, using SEM and molecular tools.

Acknowledgments: This study was carried out in the PROLITENSAN project, funded by the "Fondation de France" and by the Territorial Collectivity of Martinique. We are grateful to Dr. Florence Rousseau from the Muséum National d'Histoire Naturelle (Paris, France) for her help in macrophyte identification. Thanks to 
the health surveillance group of the Health Agency (Martinique) for their trust and exchange of data. Most authors are part of the GDR PhycoTox (Ifremer and CNRS National Research Group).

\section{References}

Accoroni, S., T. Romagnoli, A. Penna, S. Capellacci, P. Ciminiello, C. Dell'Aversano, L. Tartaglione, M. Abboud-Abi Saab, V. Giussani, V. Asnaghi, M. Chiantore and C. Totti. 2016. Ostreopsis fattorussoi sp. nov. (Dinophyceae), a new benthic toxic Ostreopsis species from the eastern Mediterranean Sea. J. Phycol. 52: 1064-1084.

Alcala, A.C., L.C. Alcala, J.S. Garth, D. Yasumura and T. Yasumoto. 1988. Human fatality due to ingestion of the crab Demania reynaudii that contained a palytoxin-like toxin. Toxicon 26: 105-107.

Bagnis, R. 1981. L'ichtyosarcotoxisme de type ciguatera: phénomène complexe de biologie marine et humaine. Oceanol. Acta 4: 375387.

Ballantine, D.L., A.T. Bardales, T.R. Tosteson and H. Dupont-Durst. 1985. Seasonal abundance of Gambierdiscus toxicus and Ostreopsis sp. in coastal waters of south-west Puerto Rico. In: (C. Gabrie and B. Salvat, eds) Proceeding of the fifth international coral reef Congress. Volume 4: Symposia and Seminars. Antenne Muséum-EPHE, Tahiti. pp. 417-422.

Ballantine, D.L., T.R. Tosteson and A.T. Bardales. 1988. Population dynamics and toxicity of natural populations of benthic dinoflagellates in southwestern Puerto Rico. J. Exp. Mar. Biol. Ecol. 119: 201-212.

Ben-Gharbia, H., O.K. Yahia, Z. Amzil, N. Chomérat, E. Abadie, E. Masseret, M. Sibat, H. Zmerli Triki, H. Nouri and M. Laabir. 2016. Toxicity and growth assessments of three thermophilic benthic dinoflagellates (Ostreopsis cf. ovata, Prorocentrum lima and Coolia monotis) developing in the Southern Mediterranean Basin. Toxins 8: 1-38.

Bomber, J.W., S.L. Morton, J.A. Babinchak, D.R. Norris and J.G. Morton. 1988. Epiphytic dinoflagellates of drift algae - another toxigenic community in the ciguatera food chain. Bull. Mar. Sci. 43: 204-214.

Botana, L.M. 2014. Seafood and freshwater toxins: pharmacology, physiology, and detection. 3rd edition. CRC Press, Boca Raton. pp. 1215.

Boucaud-Maitre, D., J.-P. Vernoux, S. Pelczar, E. Daudens-Vaysse, L. Aubert, S. Boa, S. Ferracci and R. Garnier. 2018. Incidence and clinical characteristics of ciguatera fish poisoning in Guadeloupe (French West Indies) between 2013 and 2016: a retrospective cases-series. Sci. Rep. 8: 3095.

Bourdeau, P. and R. Bagnis. 1989. Risk factors of ciguatera in the French West Indies in Saint-Barthélémy, Saint-Martin and Anguilla. Rev. Elev. Med. Vet. Pays Trop. 42: 393-410.

Carlson, R.D. and D.R. Tindall. 1985. Distribution and periodicity of toxic dinoflagellates in the Virgin Islands. In: (D.M. Anderson, A.W. White and D.G. Baden, eds) Seafood toxins. Elsevier Publisher B. V., New York, D.C. pp. 271-287.

Chinain, M., C. Gatti, M. Roué, D. Laurent and H.T. Darius. 2014. Ciguatera: aspects écologiques, biologiques et toxicologiques. Rev. Francoph. Lab. 2014: 27-39.

Coat, S., D. Monti, P. Legendre, C. Bouchon, F. Massat and G. Lepoint. 2011. Organochlorine pollution in tropical rivers (Guadeloupe): role of ecological factors in food web bioaccumulation. Environ. Pollut. 159: 1692-1701.

Cohu, S., T. Thibaut, L. Mangialajo, J.-P. Labat, O. Passafiume, A. Blanfuné, N. Simon, J.-M. Cottalorda and R. Lemée. 2011. Occurrence of the toxic dinoflagellate Ostreopsis cf. ovata in relation with environmental factors in Monaco (NW Mediterranean). Mar. Pollut. Bull. 62: 2681-2691

Cohu, S., L. Mangialajo, T. Thibaut, A. Blanfuné, S. Marro and R. Lemée. 2013. Proliferation of the toxic dinoflagellate Ostreopsis cf. ovata in relation to depth, biotic substrate and environmental factors in the North West Mediterranean Sea. Harmful Algae 24: 32-44.

Daudens, E., J. Muredda, C. Locatelli-Jouans, E. Tramis, J. Vincent, J. Iotti and M. Ledrans 2013. Vers une émergence de la ciguatera en Martinique. Le bulletin de veille sanitaire, CIRE Antilles Guyane, $n^{\circ}$ 3: 12-13.

Daudens-Vaysse, E., C. Locatelli-Jouans, Y. Adelaïde, J. Muredda, G. Cloquemin, J. Iotti and M. Ledrans. 2015. Ciguatera en Martinique: bilan de la surveillance épidémiologique. Données $1^{\mathrm{er}}$ janvier 2013 au 15 juillet 2015. Le bulletin de veille sanitaire, CIRE Antilles Guyane, n ${ }^{\circ}$ 8-9: 24. 
Delgado, G., C.H. Lechuga-Devéze, G. Popowski, L. Troccoli and C.A. Salinas. 2005. Epiphytic dinoflagellates associated with ciguatera in the northwestern coast of Cuba. Rev. Biol. Trop. 54: 299-310.

Holmes, M.J. and S.L.M. Teo. 2002. Toxic marine dinoflagellates in Singapore waters that cause seafood poisonings. Clin. Exp. Pharmacol. Physiol. 29: 829-836.

Holmes, M.J., R.J. Lewis, A. Jones and A.W.W. Hoy. 1995. Cooliatoxin, the first toxin from Coolia monotis (Dinophyceae). Nat. Toxins 3 : $355-362$.

Ledreux, A., H. Brand, M. Chinain, M.-Y.D. Bottein and J.S. Ramsdell. 2014. Dynamics of ciguatoxins from Gambierdiscus polynesiensis in the benthic herbivore Mugil cephalus: trophic transfer implications. Harmful Algae 39: 165-174.

Lee, T.C.-H., F.L.-Y. Fong, K.-C. Ho and F.W.-F. Lee. 2016. The mechanism of diarrhetic shellfish poisoning toxin production in Prorocentrum spp.: physiological and molecular perspectives. Toxins 8: 272.

Litaker, R.W., M.W. Vandersea, M.A. Faust, S.R. Kibler, M. Chinain, M.J. Holmes, W.C. Holland and P.A. Tester. 2009. Taxonomy of Gambierdiscus including four new species, Gambierdiscus caribaeus, Gambierdiscus carolinianus, Gambierdiscus carpenteri and Gambierdiscus ruetzleri (Gonyaulacales, Dinophyceae). Phycologia 48: 344-390.

Litaker, R.W., M.W. Vandersea, M.A. Faust, S.R. Kibler, A.W. Nau, W.C. Holland, M. Chinain, M.J. Holmes and P.A. Tester. 2010. Global distribution of ciguatera causing dinoflagellates in the genus Gambierdiscus. Toxicon 56: 711-730.

Nishimura, T., S. Sato, W. Tawong, H. Sakanari, K. Uehara, M.M.R. Shah, S. Suda, T. Yasumoto, Y. Taira, H. Yamaguchi and M. Adachi. 2013. Genetic diversity and distribution of the ciguatera-causing dinoflagellate Gambierdiscus spp. (Dinophyceae) in coastal areas of Japan. PLoS One 8: e60882.

Norris, D.R., J.W. Bomber and E. Balech. 1985. Benthic dinoflagellates associated with ciguatera from the Florida Keys. 1. Ostreopsis heptagona sp. nov. In: (D.M. Anderson, A.W. White and D.G. Baden, eds) Toxic dinoflagellates. Elsevier, New-York. pp. 39-44.

Okolodkov, Y.B., G. Campos-Bautista, I. Gárate-Lizárraga, J.A.G. González-González, M. Hoppenrath and V. Arenas. 2007. Seasonal changes of benthic and epiphytic dinoflagellates in the Veracruz reef zone, Gulf of Mexico. Aquat. Microb. Ecol. 47: 223-237.

Okolodkov, Y.B., F.C. Merino-Virgilio, J.A. Aké-Castillo, A.C. AguilarTrujillo, S. Espinosa-Matías and J.A. Herrera-Silveira. 2014. Seasonal changes in epiphytic dinoflagellate assemblages near the northern coast of the Yucatan Peninsula, Gulf of Mexico. Acta Bot. Mex. 107: 121-151.

Olsen, D.A., D.W. Nellis and R.S. Wood. 1984. Ciguatera in the eastern Caribbean. Mar. Fish. Rev. 46: 1-18.

Parsons, M.L., K. Aligizaki, M.-Y.D. Bottein, S. Fraga, S.L. Morton, A. Penna and L. Rhodes. 2012. Gambierdiscus and Ostreopsis: reassessment of the state of knowledge of their taxonomy, geography, ecophysiology, and toxicology. Harmful Algae 14: 107-129.

Penna, A., C. Battocchi, S. Capellacci, S. Fraga, K. Aligizaki, R. Lemée and C. Vernesi. 2014. Mitochondrial, but not rDNA, genes fail to discriminate dinoflagellate species in the genus Ostreopsis. Harmful Algae 40: 40-50.

Pérez-Arellano, J.-L., O.P. Luzardo, A.P. Brito, M.H. Cabrera, M. Zumbado, C. Carranza, A. Angel-Moreno, R.W. Dickey and L.D. Boada. 2005. Ciguatera fish poisoning, Canary Islands. Emerg. Infect. Dis. 11: 1981-1982.

Randall, J.E. 2005. Review of clupeotoxism, an often fatal illness from the consumption of clupeoid fishes. Pac. Sci. 59: 73-77.

Rhodes, L., K.F. Smith, A. Verma, B.G. Curley, D.T. Harwood, S. Murray, G.S. Kohli, D. Solomona, T. Rongo, R. Munday and S.A. Murray. 2017. A new species of Gambierdiscus (Dinophyceae) from the south-west Pacific: Gambierdiscus honu sp. nov. Harmful Algae 65: 6170

Richlen, M.L., S.L. Morton, P.H. Barber and P.S. Lobel. 2008. Phylogeography, morphological variation and taxonomy of the toxic dinoflagellate Gambierdiscus toxicus (Dinophyceae). Harmful Algae 7: 614-629.

Rosine, J., J.L. Chappert, T. Cardoso and P. Quénel. 2008. La ciguatera dans les Antilles françaises. - Premières Journées interrégionales de Veille Sanitaire dans les Antilles Guyane, Schoelcher, Martinique, 12-13 décembre.

Saint Martin, K., M. Durand-Clement and P. Bourdeau. 1988. Contribution to the study of the relations between macroalgae and Gambierdiscus toxicus (Dinophyceae), responsible for ciguatera. Cryptogam. Algol. 9: 195-202.

Shears, N.T. and P.M. Ross. 2009. Blooms of benthic dinoflagellates of the genus Ostreopsis; an increasing and ecologically important phenomenon on temperate reefs in New Zealand and worldwide. Harmful Algae 8: 916-925. 
Smith, K.F., L. Biessy, P.A. Argyle, T. Trnski, T. Halafihi and L.L. Rhodes. 2017. Molecular identification of Gambierdiscus and Fukuyoa (Dinophyceae) from environmental samples. Mar. Drugs 15: 243.

Tester, P.A., R.L. Feldman, A.W. Nau, M.A. Faust and R.W. Litaker. 2009. Ciguatera fish poisoning in the Caribbean. In: (M.A. Lang, ed) Proceedings of the Smithsonian marine science symposium. Smithsonian Institution Scholarly Press, Washington, D.C. pp. 301-311.

Tester, P.A., R.L. Feldman, A.W. Nau, S.R. Kibler and R.W. Litaker. 2010. Ciguatera fish poisoning and sea surface temperatures in the Caribbean Sea and the West Indies. Toxicon 56: 698-710.

Tripuraneni, J., A. Koutsouris, L. Pestic, P. De Lanerolle and G. Hecht. 1997. The toxin of diarrheic shellfish poisoning, okadaic acid, increases intestinal epithelial paracellular permeability. Gastroenterology 112: 100-108.

Valdiglesias, V., M.V. Prego-Faraldo, E. Pásaro, J. Méndez and B. Laffon. 2013. Okadaic acid: more than a diarrheic toxin. Mar. Drugs 11: 4328-4349.

Yasumoto, T., N. Seino, Y. Murakami and M. Murata. 1987. Toxins produced by benthic dinoflagellates. Biol. Bull. 172: 128-131. 